\title{
The Effect of Chemical Sympathectomy on Catecholamine Release at Birth
}

\author{
YOUTARO AGATA, JAMES F. PADBURY, JOHN K. LUDLOW, DAN H. POLK, AND \\ JAMES A. HUMME \\ Perinatal Research Laboratories, Harbor-UCLA Medical Center, Torrance, California 90509
}

\begin{abstract}
The precise source of circulating catecholamine (CA) at birth and their role in circulatory adaptation is unclear. In order to determine the contribution of increased postganglionic sympathetic nerve activity to the CA surge at birth, we induced complete sympathectomy in near term fetal lambs prior to delivery by giving 6-hydroxydopamine. Chronically catheterized fetal sheep received either 6-hydroxydopamine $(n=5)$ or control infusion $(n=$ $6)$. Chemical sympathectomy was verified by tyramine infusion. Lambs were delivered at $142 \pm 1$ days of gestation and serial plasma $\mathrm{CA}$, heart rate, blood pressure, cardiac output, blood gases, blood glucose, and free fatty acids, were measured before and for $4 \mathrm{~h}$ after delivery. Myocardial $\beta$-adrenergic receptors and tissue $\mathrm{CA}$ concentration were determined following sacrifice. Baseline circulating norepinephrine (NE) values were lower in sympathectomized animals $(183 \pm 45$ versus $373 \pm 125 \mathrm{pg} / \mathrm{ml}, p<$ $0.05)$ and epinephrine values were slightly higher (118 \pm 89 versus $48 \pm 1 \mathrm{pg} / \mathrm{ml}$, NS). There was only a 2 -fold increase in $\mathrm{NE}$ after cord cutting in sympathectomized animals while control animals had a 4-fold increase (peak $\mathrm{NE}$ values $354 \pm 121$ versus $1305 \pm 363 \mathrm{pg} / \mathrm{ml}$ respectively, $p<0.001$ ). Epinephrine increased significantly in both groups and there were no significant differences between sympathectomized and control animals. Heart rate and blood pressure rose abruptly in both groups after cord cutting and there were no significant differences. Cardiac output was similar in both groups. Blood glucose in sympathectomized animals was significantly higher than control before $(p<0.005)$ and after $(p<0.001$, peak values $66 \pm 15$ versus $35 \pm 12 \mathrm{mg} / \mathrm{dl})$. Plasma free fatty acid levels rose after cord cutting and were similar in both groups. Tissue NE content in the hearts of sympathectomized animals were less than 5\% of control (mean $1.92 \pm$ $0.5 \%$, verifying the completeness of sympathectomy in this tissue. Myocardial $\beta$-adrenergic receptors were $229 \pm$ 21 versus $199 \pm 26 \mathrm{fmol} / \mathrm{mg}$ protein in sympathectomized and control animals, respectively. These results suggest that the majority of circulating NE seen at birth arises from postganglionic sympathetic neurons rather than adrenal medullary secretion. The comparable hemodynamic and metabolic homeostasis of the two groups underscores the importance of increased circulating adrenal epinephrine at birth. (Pediatr Res 20: 1338-1344, 1986)
\end{abstract}

\section{Abbreviations}

6OHDA, 6-hydroxydopamine

CA, catecholamine

Received May 30, 1986; accepted August 4, 1986.

Reprint requests James F. Padbury, M.D., Harbor-UCLA Medical Center, 1000 West Carson Street, Torrance, CA 90509

This work was supported by Grant HD18014 from NICHHD and a Basil O'Connor Starter Research Grant from the National Foundation March of Dimes.

\author{
NE, norepinephrine \\ E, epinephrine \\ CO, left ventricular cardiac output \\ FFA, free fatty acid \\ BAR, $\beta$-adrenergic receptor \\ ANOVA, analysis of variance
}

Marked elevations of plasma CA occur at birth in animals and newborn humans (1-5). Studies with chronically catheterized fetal sheep have demonstrated that the increase in circulating CA begins during the last 2-3 h of spontaneous labor (5). Following delivery and umbilical cord cutting, there is a further augmentation in CA levels. Total increases in NE of 5- to 10-fold and $\mathrm{E}$ 10 - to 20 -fold over basal levels are observed (1-4).

Increased levels of plasma CA have been suggested to be useful indicators of increased sympathoadrenal activity $(6,7)$. However, the results of previous studies in the newborn have not demonstrated the source of the circulating CA. Plasma NE represents spillover from postganglionic sympathetic neurons as well as secretion from chromaffin tissues of adrenal medullary and extramedullary origin. However, there is reportedly no extramedullary chromaffin tissue in fetal or newborn sheep (8; Coupland $\mathrm{RE}$, personal communication; Padbury $\mathrm{JF}$, unpublished observations). In the fetal sheep secretion from the adrenal medulla can be neurally induced or stimulated directly in response to hypoxia. The latter evolves a predominant NE response while the nature of the neurally mediated response depends on the degree of fetal development (9). As term gestation is approached, the proportion of $\mathrm{E}$ in the adrenal medulla increases (10). Similarly, the magnitude of the neuronal component of fetal adrenal CA secretion and the proportion of $E$ release in response to asphyxia increase near term. In the sheep fetus the adrenal medulla is unresponsive to nerve stimulation until the last 20 days of fetal life. There is then a very rapid increase in adrenal CA secretion and an increase in the proportion of $E$ released in response to nerve stimulation $(9,10)$. Similar findings have been described in neonatal rats where loss of the direct, nonneurogenic, response, and development of neural control of catecholamine release occurs after the first postnatal week (11).

We were interested therefore to determine the separate contributions of increased postganglionic sympathetic nerve activity and adrenal medullary CA secretion to the CA surge at birth. We were also interested in determining the separate contribution of postganglionic nerve activity and adrenal medullary CA secretion to the maintenance of hemodynamic and metabolic homeostasis in the newborn period. To perform these studies we used 6OHDA to cause chemical denervation of a catheterized fetal sheep (12). Following demonstration of complete sympathetic denervation, treated animals and controls were delivered and supported as previously described (2). Serial measurements of 
plasma CA, blood pressure, heart rate, CO, FFA, and glucose were compared in the two groups.

\section{METHODS}

Animals. Previously acclimated Western mixed breed ewes with time-dated, twin pregnancies were operated on at $138 \pm 0.9$ days (term is 150 days). After an overnight fast, the ewes were premedicated with ketamine $(750 \mathrm{mg})$ and atropine $(1.2 \mathrm{mg})$ and then maternal jugular venous catheterization was performed and anesthesia was maintained by continuous infusion of ketamine at $5 \mathrm{mg} / \mathrm{min}$ during surgery. The abdomen was shaved and prepped in the usual fashion and the uterus was exposed through midline abdominal incision. The fetal hindlimb was identified, delivered through a small hysterotomy, and polyvinyl catheters were inserted from the pedal artery and vein to the level of the midabdomen. The fetal hindlimb of the second animal was then identified, delivered through another small hysterotomy, and polyvinyl catheters were similarly placed. Local infiltration of $1 \%$ lidocaine was carried out prior to all incisions. Following repair of each hysterectomy, the catheters were tunneled through the maternal flank, secured, and stored in a pouch. Ampicillin and chloramphenicol ( $1 \mathrm{~g}$ each) were given to the ewe and 250 $\mathrm{mg}$ ampicillin to the fetus on the day of surgery and daily thereafter for 5 days.

On the 2 nd day after surgery, a $1 \mathrm{mg} / \mathrm{kg}$ test dose of 6 OHDA (Sigma) was given to one fetus and on the $3 \mathrm{rd}$ day $50 \mathrm{mg} / \mathrm{kg}$ of 6 OHDA was given to the same fetus. Fetal weight was estimated from our own birth weight data from twin animals of a similar gestational age and provided by the same supplier. The drug was dissolved in $10 \mathrm{ml}$ of normal saline containing $1 \mathrm{mg} / \mathrm{ml}$ of ascorbic acid and was administered over a period of $2-3 \mathrm{~h}$. Simultaneously $10 \mathrm{ml}$ of normal saline containing $1 \mathrm{mg} / \mathrm{ml}$ of ascorbic acid was given to the other fetus at the same infusion rate. Heart rate and blood pressure were measured continuously in both fetuses during the infusions. On the 4th postoperative day, $150-200 \mu \mathrm{g} / \mathrm{kg}$ of tyramine was given to each fetus to verify whether chemical sympathectomy by 6OHDA was complete (13).

Delivery studies. On the 6th postoperative day the ewes were premedicated with $750 \mathrm{mg}$ of ketamine and $1.5 \mathrm{mg}$ of atropine, followed by spinal/epidural anesthesia. This dose of ketamine has been shown not to affect fetal CA levels significantly (14). The uterus was exposed through a midline abdominal incision and individual fetal parts were identified by palpation. The fetal head and neck were delivered through a uterine incision and fetal breathing was prevented by immediately placing a warm saline filled glove over the head. Following local anesthetic infiltration, a tracheostomy was performed through a midline, longitudinal incision with secure placement of an appropriately sized, uncuffed Portex endotracheal tube. A catheter was inserted via the right common carotid artery into the left ventricle while the pressure tracing was monitored. Position was confirmed by oscilloscopic monitoring of the wave form throughout the course of the study. The animals were delivered onto the maternal abdomen and allowed to stabilize for 20 to $30 \mathrm{~min}$. Care was taken to avoid traction or trauma to the umbilical cord. Heart rate and blood pressure were monitored continuously with a pressure transducer connected to the hindlimb arterial catheter. Body temperature was monitored with an indwelling rectal probe. Blood samples for CA, blood gases, FFA, and glucose measurements were drawn serially from hindlimb arterial catheter until the time of cord cutting. Baseline measurements were carried out at $-20,-10,-5$, and 0 min and referred to zero time as cord clamping. Immediately after cord cutting, the animals were ventilated by hand with $100 \%$ oxygen and placed on timecycled, pressure limited Sechrist infant ventilators. The ventilator was adjusted to maintain $\mathrm{pH}$ and $\mathrm{pCO}_{2}$ within normal values which were measured frequently. Fractional inspired oxygen was adjusted to maintain $\mathrm{pO}_{2}$ between 100 and $150 \mathrm{~mm} \mathrm{Hg}$. The lambs were dried superficially and supported under an infant warmer with supplemental heat lamps as necessary to maintain body temperature at $39 \pm 1.0^{\circ} \mathrm{C}$. For hemodynamic monitoring and blood sampling, a catheter was placed through the umbilical artery to the level of the abdominal aorta. Heart rate and blood pressure were measured continuously and recorded on a multichannel Sensormedic polygraph. Heart rate, blood pressure, and blood samples were obtained at $5,15,30,60,120,180$, and 240 min after cord cutting. Four milliliters of blood were collected at each time point and samples were replaced with fresh, heparinized residual placental blood $(1 \mathrm{U} / \mathrm{ml}$ blood). To prevent movement, the animals were paralyzed with pancuronium bromide. A continuous infusion of normal saline at $100 \mathrm{ml} / \mathrm{kg} / 24 \mathrm{~h}$ was administered through the umbilical arterial catheter.

$\mathrm{CO}$ was measured at 30,90 , and $240 \mathrm{~min}$ after cord cutting using 15- $\mu$ diameter microspheres labeled with ${ }^{125} \mathrm{I},{ }^{85} \mathrm{Sr}$, and ${ }^{46} \mathrm{Sc}$. Each microsphere was suspended in $6 \mathrm{ml}$ of heparinized blood which was infused into the left ventricle over $60 \mathrm{~s}$. Concurrent with each injection of microspheres, a reference sample was withdrawn in a preweighed, heparinized glass syringe at a rate of $6 \mathrm{ml} / \mathrm{min}$ for $2 \mathrm{~min}$ from the descending aorta. The volume withdrawn was replaced simultaneously with heparinized blood. The syringe was reweighed after withdrawal in order to calculate the volume of blood withdrawn.

Tissue analysis. Immediately after taking the last samples and $\mathrm{CO}$ measurement, the lambs were sacrificed by pentobarbital overdose and 50-100 mg of tissue was taken rapidly from the right and left atrial appendage, the right and left ventricle, the middle lobe appendage of right lung, the entire left adrenal gland and left perinephric brown fat for tissue CA assay. After weighing, the tissues were immersed in iced $0.1 \mathrm{M}$ perchloric acid with 5 $\mathrm{mM}$ reduced glutathione and immediately homogenized. Homogenates were centrifuged and the supernatant was removed, quick frozen, and stored at $-70^{\circ} \mathrm{C}$ for later $\mathrm{CA}$ analysis. An aliquot was stored for protein determination by the method of Lowry et al. (15).

The remainder of the ventricular tissue was trimmed of residual atrial tissue, atrioventricular valves, and connective tissue and used for the BAR assay. The ventricles were washed with cold buffer and homogenized in six volumes of iced $250 \mathrm{mM}$ sucrose, $5 \mathrm{mM}$ Tris-HCl pH 7.4, and $1 \mathrm{mM} \mathrm{MgCl}_{2}$. The homogenate was centrifuged for $10 \mathrm{~min}$ at $3000 \times g$. The supernatant was decanted and centrifuged at $40,000 \times g$ for $20 \mathrm{~min}$ and the pellet was stored for later microsphere counting. The resultant supernatant was discarded and the pellet resuspended in homogenizing buffer and centrifuged again. The resulting homogeneous pellet was resuspended to a final protein concentration of 3 to 5 $\mathrm{mg} / \mathrm{ml}$, separated into aliquots, and quick frozen with dry ice and ethanol. Membranes thus prepared were stored at $-70^{\circ} \mathrm{C}$ until assay, usually within $1 \mathrm{wk}$.

Analytical techniques. Plasma or tissue CA were measured in duplicate plasma aliquots or perchloric acid tissue extracts, respectively. The basis of the assay is enzymatic methylation of $\mathrm{CA}$ to their $O$-methyl derivatives which are then separated by thin-layer chromatography, extracted, periodated and counted in a liquid scintillation spectrometer. The sensitivity of plasma $\mathrm{CA}$ assay is 1 to $2 \mathrm{pg}$ for $\mathrm{NE}$ and $\mathrm{E}$, and sensitivty in perchloric acid was $2-5 \mathrm{pg}$ for $\mathrm{NE}$ and $\mathrm{E}(16,17)$.

Direct binding studies for BAR were performed as previously described (18). Briefly, membrane fractions were added in duplicate to $50 \mathrm{mM}$ Tris $\mathrm{HCl} \mathrm{pH} \mathrm{7.4,10} \mathrm{mM} \mathrm{MgCl}$ with concentrations of tritiated dihydroalprenolol $\left({ }^{3} \mathrm{H}-\mathrm{DHA}\right.$, specific activity $45-50 \mathrm{Ci} / \mathrm{mmol}$ ) ranging from 0.5 to $5 \mathrm{nM}$. Bound and free material were separated by rapid filtration and washing on Whatman GF/C glass fiber filters and were counted in a liquid scintillation system. Nonspecific binding was defined as the amount of ${ }^{3} \mathrm{H}-\mathrm{DHA}$ bound in the presence of $1 \mu \mathrm{M} \mathrm{D}, \mathrm{L}-$ propranolol. The protein concentration of the membrane preparation was determined by the method of Lowry et al. (15). Maximal binding capacity, expressed at fmol ${ }^{3} \mathrm{H}-\mathrm{DHA}$ bound 
per mg of membrane protein, and the dissociation constant, $\mathrm{Kd}$, were determined by Scatchard analysis of the direct binding data as previously described (18).

All blood gas measurements were conducted using $0.3 \mathrm{ml}$ heparinized blood and a Radiometer blood gas analyzer with temperature corrected to $39^{\circ} \mathrm{C}$. FFA were measured using a microcolorimetric assay (19). Glucose was measured with a glucose analyzer (YSI model 23A Glucose Analyzer).

Microsphere techniques. The whole body of the lamb was incinerated at $325^{\circ} \mathrm{C}$ for $72 \mathrm{~h}$, ground into a coarse powder, and placed into glass tubes. Care was taken to equalize the height of contents in all tubes. Radioactivity of each radioisotope was counted in a multichannel $\gamma$ spectrometer (CG-30, Inter-technique). The entire pellet and residual cardiac tissue obtained from ventricles were counted directly, and the reference blood samples were also counted directly. The $\mathrm{CO}(\mathrm{ml} / \mathrm{kg}$ body weight/ $\mathrm{min}$ ) was calculated from the radioactivity present in the referenced blood samples and the total radioactivity injected into the animal as previously described $(20,21)$. Total systemic resistance $(\mathrm{mm} \mathrm{Hg} / \mathrm{ml} / \mathrm{min} / \mathrm{kg}$ ) was calculated from the $\mathrm{CO}$ and mean systemic pressure.

Statistics. Comparisons between sequential plasma CA values and other parameters from denervated animals versus controls were done by two-way ANOVA (22). Individual comparisons between or within groups were made by unpaired Student's $t$ test. All data are presented as mean \pm SE.

\section{RESULTS}

A total of 10 ewes with twin gestations was operated on. The two fetuses in one animal died on the 1st postoperative day because of diarrhea and prostration in the ewe. Two fetuses died following 6OHDA administration with severe acidosis on the day preceding delivery and one control lamb died during delivery from accidental cord occlusion. The remaining 15 lambs (eight denervated and seven control lambs) survived throughout the experiment. One control fetus and three 6OHDA-treated animals had severe hypoxia and acidosis at the time of delivery and are reported below as asphyxiated animals. The remaining five denervated and six control animals were used for sequential studies of plasma CA, hemodynamic, and metabolic responses to delivery.

An average of $44 \pm 2 \mathrm{mg} / \mathrm{kg}$ of $6 \mathrm{OHDA}$ was given to each animal in the denervated group. The initial dose of drug did not produce significant effects on heart rate and blood pressure; however, larger doses resulted in significantly increased heart rate and blood pressure during drug infusion (heart rate baseline $154 \pm 11$ beats per min; peak $195 \pm 9$ beats per min; blood pressure baseline $50 \pm 2 \mathrm{~mm} \mathrm{Hg}$, peak $75 \pm 6 \mathrm{~mm} \mathrm{Hg}$ ). Controls did not show any significant changes in heart rate or blood pressure during the infusion of normal saline containing $1 \mathrm{mg} /$ $\mathrm{ml}$ of ascorbic acid and did not show any responses to the 6OHDA which was received by the other twin.

Subsequently, tyramine infusion $(178 \pm 8 \mu \mathrm{g} / \mathrm{kg})$ in control animals resulted in significant blood pressure increases from 53 \pm 2 to $63 \pm 2 \mathrm{~mm} \mathrm{Hg}(p<0.01)$, and heart rate decreases from $144 \pm 11$ to $129 \pm 25$ beats per min $(p<0.05)$. In contrast, animals treated with 6OHDA showed no significant changes in blood pressure or heart rate.

The results of sequential plasma $\mathrm{NE}$ and $\mathrm{E}$ responses in the nonasphyxiated denervated and control animals are shown in Figure 1; panel $A$ shows plasma NE values. NE of the denervated group did not show the usual marked increase after cord cutting. Baseline (prior to cord cutting) NE in 6OHDA animals was 183 $\pm 45 \mathrm{pg} / \mathrm{ml}$, rising to a peak of $354 \pm 121 \mathrm{pg} / \mathrm{ml}$ at $120 \mathrm{~min}$. In contrast, control animals demonstrated significantly higher baseline NE concentrations $(373 \pm 125 \mathrm{pg} / \mathrm{ml}, p<0.05)$ which rose to $1305 \pm 363 \mathrm{pg} / \mathrm{ml}$ by $5 \mathrm{~min}$ after cord cutting. The peak response between control and 6OHDA animals was significantly different as was the overall response $(p<0.001$, two-way

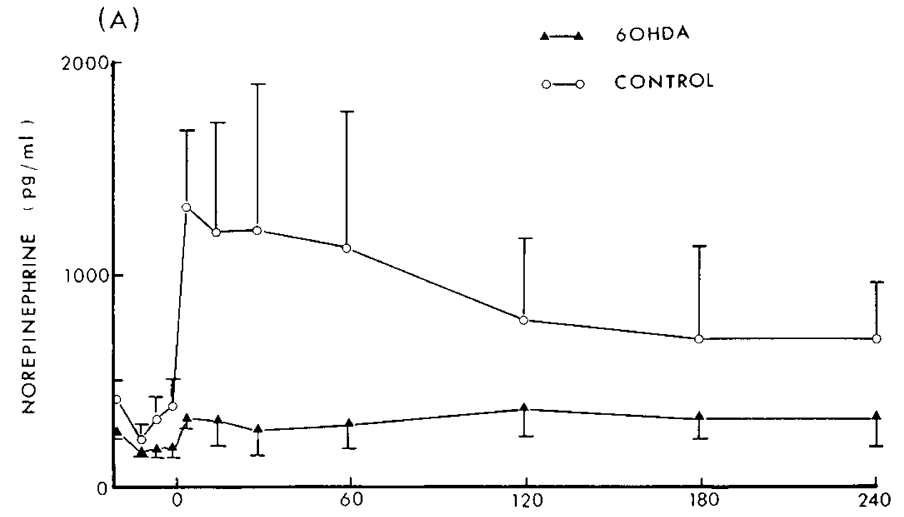

(B)

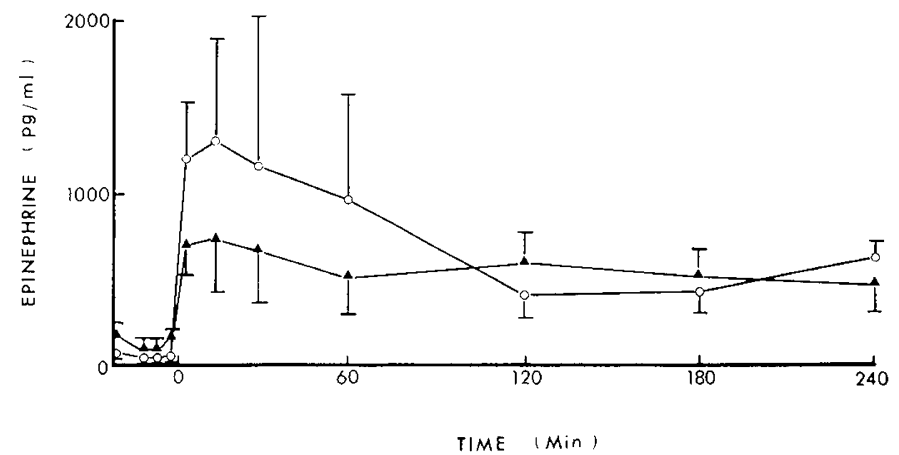

Fig. 1. $A$, plasma norepinephrine $(\mathrm{pg} / \mathrm{ml})$ in denervated $(\boldsymbol{\Lambda})$ and control $(O)$ lambs. Zero time refers to the time of umbilical cord cutting. Values are recorded as mean and SE. Values for denervated and control lambs compared by two-way ANOVA during the period before $(p<$ $0.05)$ and after cord cutting $(p<0.001)$. Assay as described in "Methods." $B$, plasma epinephrine $(\mathrm{pg} / \mathrm{ml})$ in the same animals. Values for denervated and control animals compared by two-way ANOVA during the period before (NS) and after cord cutting (NS). Assay as described in "Methods."

ANOVA). The response in the control animals was nearly identical to our previously reported observations in animals of a similar gestational age (2). Figure $1 B$ shows the plasma $E$ values. The $E$ values of the denervated group increased markedly after cord cutting from $118 \pm 89 \mathrm{pg} / \mathrm{ml}$ immediately prior to cord cutting to $730 \pm 324 \mathrm{pg} / \mathrm{ml}$ at $15 \mathrm{~min}$ after cord cutting. The control group also showed striking increases after cord cutting from less than $100 \mathrm{pg} / \mathrm{ml}$ before cord cutting to $1306 \pm 600 \mathrm{pg} /$ $\mathrm{ml}$ at $15 \mathrm{~min}$ after cord cutting. There were no significant differences between the two groups by ANOVA and the peak levels of both groups did not differ significantly when analyzed by Student's $t$ test. In contrast, baseline NE and $\mathrm{E}$ in the asphyxiated, denervated animals were $6189 \pm 2808$ and $7496 \pm$ $3563 \mathrm{pg} / \mathrm{ml}$, respectively. The single asphyxiated control fetus had a baseline NE of $3,818 \mathrm{pg} / \mathrm{ml}$ and $E$ of $18,177 \mathrm{pg} / \mathrm{ml}$.

The serial heart rate, blood pressure, $\mathrm{pH}$, and arterial blood gas values for the control and denervated animals are shown in Figure 2. As can be seen, heart rate and blood pressure increased significantly in both groups following umbilical cord cutting and to comparable levels. Heart rate increases in the denervated group were from $157 \pm 10$ to $228 \pm 8$ beats per min, and in the control group from $150 \pm 13$ to $207 \pm 7$ beats per minute. Mean blood pressures prior to cord cutting in the denervated group, 53 $\pm 7 \mathrm{~mm} \mathrm{Hg}$, increased to $80 \pm 4 \mathrm{~mm} \mathrm{Hg}$. In the control group these changes were from $53 \pm 3$ to $72 \pm 3 \mathrm{~mm} \mathrm{Hg}$, respectively. The increases following umbilical cord cutting were highly significant. The two groups were otherwise comparable to one another and comparable to the data previously reported (2). 
(B)
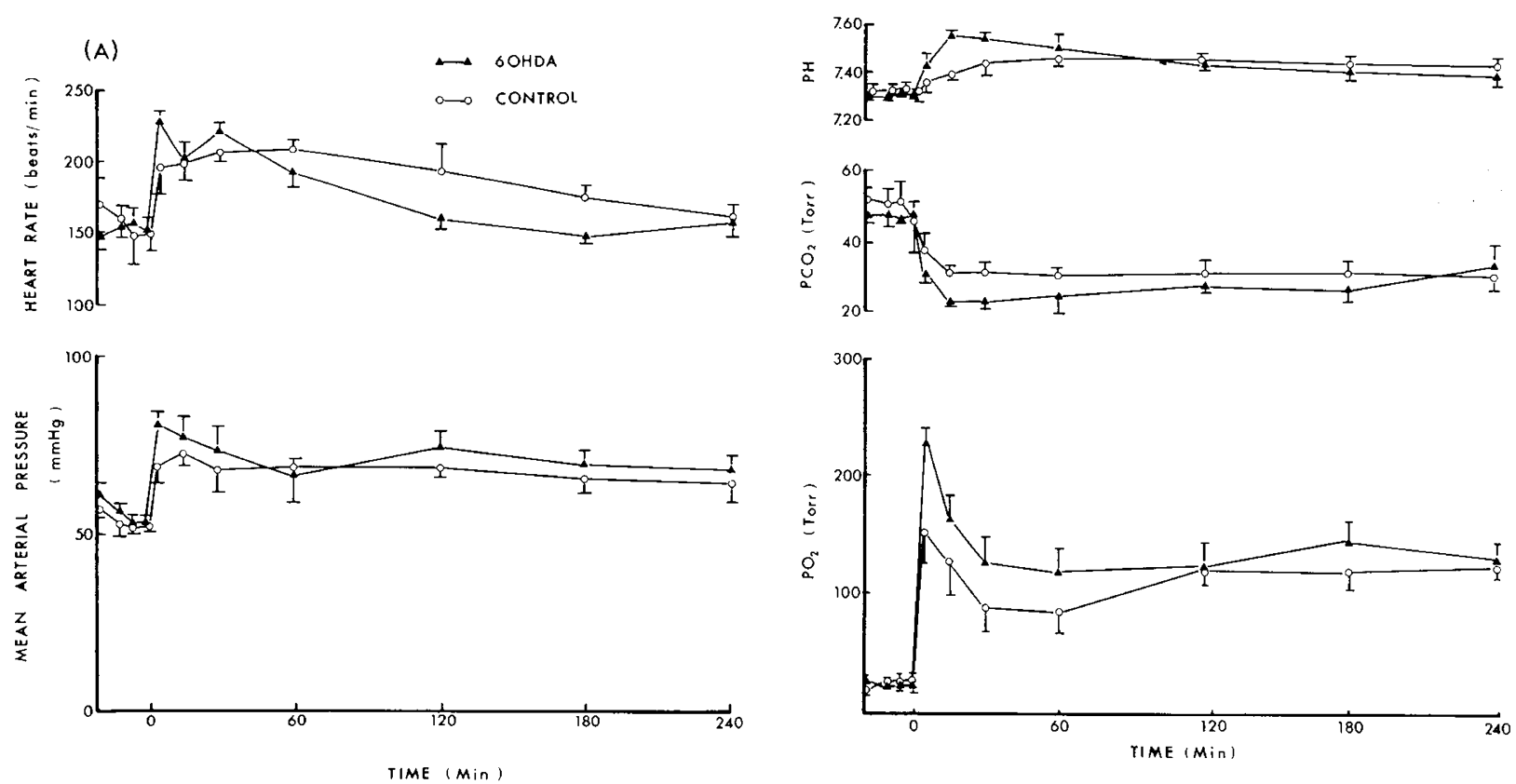

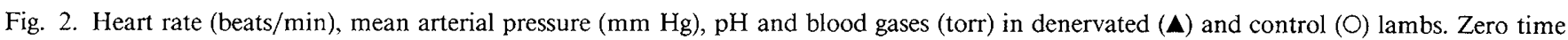
refers to the time of umbilical cord cutting. Values are recorded as mean and SE. Assays as described in "Methods."

Serial blood gases and $\mathrm{pH}$ are shown in Figure $2 B$. Baseline $\mathrm{pO}_{2}, \mathrm{pCO}_{2}$, and $\mathrm{pH}$ were similar in the control and denervated animals prior to umbilical cord cutting $\left(\mathrm{pO}_{2} 24 \pm 7\right.$ versus $27 \pm$ $6 \mathrm{~mm} \mathrm{Hg}, \mathrm{pCO}_{2} 46 \pm 9$ versus $48 \pm 3 \mathrm{~mm} \mathrm{Hg}$, and $\mathrm{pH} 7.32 \pm$ 0.04 versus $7.31 \pm 0.01$, respectively). Comparable levels of oxygenation were maintained in both groups following umbilical cord cutting and the initiation of ventilation. As can be seen, the values remained within a physiologic range for both groups throughout the period of study. There was a tendency for a mild respiratory alkalosis in the denervated group, however, these differences were just at the level of significance $(p<0.05)$. Initial blood gases in the asphyxiated animals, in contrast, revealed a $\mathrm{pO}_{2}$ of $13 \pm 1, \mathrm{pCO}_{2}$ of $75 \pm 14$, and $\mathrm{pH} 7.04 \pm 0.14$.

The plasma FFA value for control and denervated animals are shown in Figure $3 A$. Both groups of animals had similar baseline values. There was a 4 - to 5-fold increase in peak FFA concentrations in both groups after cord cutting. In control animals the FFA concentration reached a peak value of $615 \pm 108 \mu \mathrm{Eq} /$ liter at 30 min after cord cutting and remained elevated throughout the 4-h observation. The pattern of increase after cord cutting in denervated animals resembled that of control animals; a peak value of nearly $500 \mu \mathrm{Eq} /$ liter was reached by $30 \mathrm{~min}$ and maintained for the $4 \mathrm{~h}$ of observation.

The changes in blood glucose concentration in control and denervated animals are shown in Figure $3 B$. Baseline values of denervated animals were significantly higher than those of the control groups $(p<0.05)$. After cord cutting there was a gradual increase which reached a peak value of $66 \pm 15 \mathrm{mg} / \mathrm{dl}$ at 120 min in denervated animals. In control animals there was also a gradual increase however the peak value, $35 \pm 12 \mathrm{mg} / \mathrm{dl}$ at 120 min, was significantly less than in denervated animals $(p<0.01)$.

The tissue CA values are shown in Table 1 . The NE values of right and left atria, right and left ventricles were presented as combined values because there were no significant differences between right and left atria or ventricles. All the tissue NE concentrations in the atria and ventricles obtained from denervated groups were less than $5 \%$ of those of control groups (mean $1.9 \pm 0.5 \%$ ), verifying the completeness of sympathectomy in this tissue. The NE concentration in lung tissue was variable and there were no differences between the groups. The NE concentration in brown adipose tissue decreased by $43 \%$ in the dener-

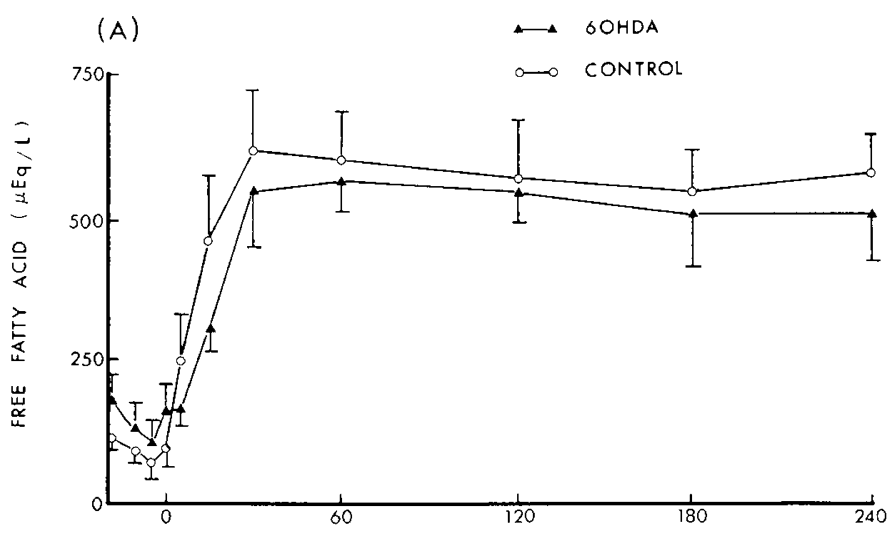

(B)

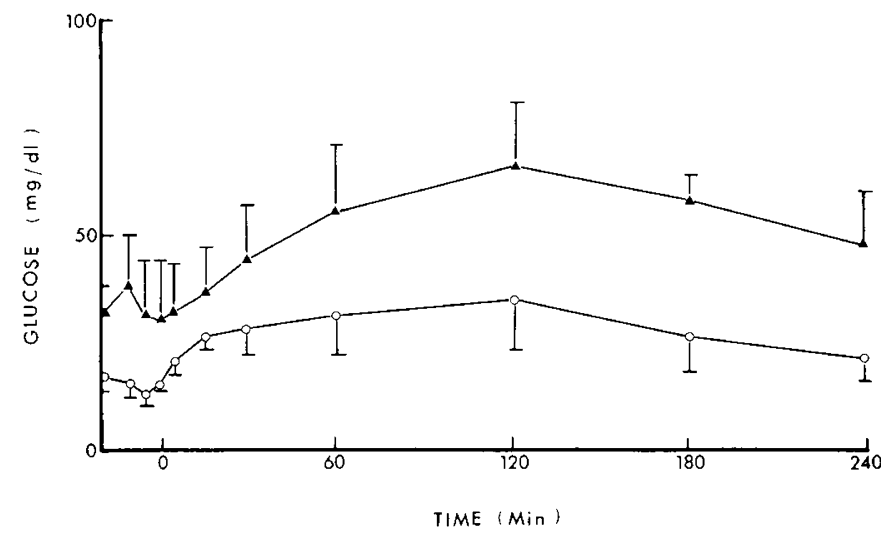

Fig. 3. $A$, plasma FFA $(\mu \mathrm{Eq} /$ liter $)$ in denervated $(\mathbf{\Lambda})$ and control $(O)$ lambs. Zero time refers to the time of umbilical cord cutting. Values are recorded as mean and SE. Assay as described in "Methods." $B$, blood glucose $(\mathrm{mg} / \mathrm{dl})$ in the same animals. Values for denervated and control animals compared by two-way ANOVA during the period before $(p<$ $0.005)$ and after cord cutting $(p<0.001)$. Assay as described in "Methods." 
Table 1. Tissue NE concentration (pg/mg protein) and total adrenal catecholamine content ( $\mu \mathrm{g} / \mathrm{gland}$ ) from control and $60 \mathrm{OHDA-}$ treated animals*

\begin{tabular}{cccc}
\hline & $\begin{array}{c}\text { Atria } \\
(\mathrm{pg} / \mathrm{mg} \\
\text { protein) }\end{array}$ & $\begin{array}{c}\text { Ventricle } \\
(\mathrm{pg} / \mathrm{mg} \\
\text { protein) }\end{array}$ & $\begin{array}{c}\text { Lung } \\
(\mathrm{pg} / \mathrm{mg} \\
\mathrm{protein})\end{array}$ \\
\hline 6OHDA & $665 \pm 146 \dagger$ & $399 \pm 124 \dagger$ & $13,703 \pm 1167$ \\
Control & $32,750 \pm 4656$ & $41,865 \pm 5965$ & $13,650 \pm 1218$
\end{tabular}

Adrenal catecholamine content

\begin{tabular}{lcc} 
& $\begin{array}{c}\text { Norepinephrine } \\
(\mu \mathrm{g} / \text { gland })\end{array}$ & $\begin{array}{c}\text { Epinephrine } \\
(\mu \mathrm{g} / \mathrm{gland})\end{array}$ \\
\hline 6OHDA & $37.0 \pm 8.3$ & $32.8 \pm 6.5$ \\
Control & $29.6 \pm 6.8$ & $29.9 \pm 4.3$ \\
\hline
\end{tabular}

* Assays as described in "Methods." Results are mean \pm SEM.

$\dagger$ Denotes significant difference $(p<0.05)$.

Table 2. Left ventricular output, myocardial blood flow, and total systemic resistance in control and chemically denervated

\begin{tabular}{|c|c|c|c|c|c|c|}
\hline & \multicolumn{2}{|c|}{$\begin{array}{c}30 \text { min after } \\
\text { cord cutting } \\
\left({ }^{125} \mathrm{I}\right)\end{array}$} & \multicolumn{2}{|c|}{$\begin{array}{l}90 \text { min after } \\
\text { cord cutting } \\
\quad\left({ }^{85} \mathrm{Sr}\right)\end{array}$} & \multicolumn{2}{|c|}{$\begin{array}{l}240 \text { min after } \\
\text { cord cutting } \\
\quad\left({ }^{46} \mathrm{Sc}\right)\end{array}$} \\
\hline & 6OHDA & Control & $6 \mathrm{OHDA}$ & Control & 6OHDA & Control \\
\hline $\begin{array}{l}\text { Left ventricular output (ml/ } \\
\mathrm{kg} / \mathrm{min})\end{array}$ & $221 \pm 27$ & $194 \pm 29$ & $204 \pm 20$ & $266 \pm 36$ & $195 \pm 37$ & $232 \pm 36$ \\
\hline $\begin{array}{l}\text { Myocardial blood flow }(\mathrm{ml} / \\
100 \mathrm{~g} / \mathrm{min})\end{array}$ & $247 \pm 98$ & $242 \pm 70$ & $174 \pm 43$ & $237 \pm 48$ & $134 \pm 48$ & $143 \pm 35$ \\
\hline $\begin{array}{l}\text { Total systemic resistance } \\
(\mathrm{mm} \mathrm{Hg} / \mathrm{ml} / \mathrm{kg} / \mathrm{min})\end{array}$ & $0.349 \pm 0.052$ & $0.370 \pm 0.063$ & $0.382 \pm 0.064$ & $0.269 \pm 0.040$ & $0.375 \pm 0.071$ & $0.299 \pm 0.059$ \\
\hline
\end{tabular}

* Results are mean $\pm \mathrm{SE}$.

vated groups but the difference was not significant $(p<0.1)$. The NE and $E$ content of the adrenal gland showed no differences between the two groups.

$\mathrm{CO}$, myocardial blood flow, and total systemic resistance for two groups are shown in Table 2. There were no significant differences in serial $\mathrm{CO}$ in each group or between the two groups. Myocardial blood flow and total systemic resistance did not show any differences between two groups.

Because of previous studies suggesting denervation hypersensitivity following 6OHDA administration (23), we were interested to compare myocardial BAR in these two groups. The concentration of BAR in denervated groups was higher than that of control groups, however, this difference was not significant. Maximal binding capacity was $229 \pm 21$ and $199 \pm 26 \mathrm{fmol} / \mathrm{mg}$ protein in denervated and control groups, respectively. Kds were similar in both groups and were $3.2 \pm 0.5 \mathrm{nM}$ in denervated animals and $2.9 \pm 0.4 \mathrm{nM}$ in control animals.

\section{DISCUSSION}

6OHDA is a synthetic CA which causes acute depletion of sympathetic neuronal stores of NE followed by histologic, electronmicrographic, and biochemical evidence of prolonged destruction of postganglionic sympathetic neurons. Its use in experimental models has been extensive (12) and recent studies have been conducted in fetal and newborn sheep to investigate the role of the sympathetic nervous system in responses to hypoxia and circulatory control $(13,23,24)$. In order to investigate the origin of increased circulating CA at birth in newborn lambs we performed chemical sympathectomy with 6OHDA on chronically catheterized fetal sheep. Following demonstration of complete sympathectomy, the animals were delivered and their $\mathrm{CA}$ responses were compared to control animals. Our data show that NE increased only 2 -fold at delivery in denervated animals whereas in the control animals NE increased 4-fold above basal levels. The changes in NE in the control animals are comparable to previously reported data from intact animals at similar gestational age (2) and when compared to the NE responses in the denervated animals suggest that the majority of circulating $\mathrm{NE}$ following delivery is derived from increased postganglionic sympathetic nerve activity rather than adrenal medullary secretion. However, the marked elevations in NE levels in the asphyxiated denervated animals also suggests that the degree of adrenal NE release is dependent on the severity of asphyxia or hypoxia. It is also important to note that since birth by cesarian section results in a lower CA surge than vaginal delivery in human infants (25), it is possible that greater degrees of adrenal NE release may be seen in the denervated sheep following a vaginal delivery. This delivery model was used because the responses are well characterized and it allows optimum control over the highly variable effects of labor, manipulation, delivery, and cord cutting.

6OHDA is not reported to affect adrenal medullary CA content or secretion $(13,23,24,26)$. This is consistent with our observation that $\mathrm{E}$ in both groups increased markedly after cord cutting, reaching concentrations 5- to 7-fold higher than basal levels. There was no significant difference between the control and denervated animals. There was also no difference in adrenal CA content. There was, however, more variability in E secretion in both groups than we have previously observed. There may have been some direct effect of 6OHDA on adrenal function although this is said not to occur. Lewis et al. (13) performed chemical sympathectomy with 6OHDA in chronically catheterized fetal sheep and then subjected them to hypoxia. NE responses were only reduced marginally in the denervated animals but the $\mathrm{E}$ responses were markedly decreased. The mechanisms for this observation is not clear.

We observed comparable circulatory changes at birth in the control and denervated animals, despite documentation by tissue $\mathrm{CA}$ analysis of the completeness of the sympathectomy in the heart. Heart rate increased $50-70$ beats per $\mathrm{min}$ and blood pressure increased $20-30 \mathrm{~mm} \mathrm{Hg}$ after cord clamping and $\mathrm{CO}$ was well above fetal values and comparable to values reported 
for intact animals at birth at this gestational age $(27,28)$. Total systemic resistance was comparable in the two groups. This suggests that the increase in $\mathrm{E}$ at birth is more important in the maintenance of circulatory homeostasis than NE released from sympathetic neurons in the myocardium. The sympathetic system of the developing heart in most species is structurally and functionally immature (29). Lebowitz et al. (30) noted histofluorescent evidence for myocardial sympathetic innervation in fetal sheep by 100-110 days gestation, however, innervation was still not complete by term. Similarly, the development of the myocardial BAR-effector complex is occurring concomitantly with the ingrowth of sympathetic nerves (31). Cardiovascular responses of fetal lambs to neurotransmitters such as NE increase with gestational age, however, the fetal circulation is still less reactive than adult sheep (32). Circulatory changes at birth result in sudden elevations in $\mathrm{CO}$, systemic arterial pressure, and vascular resistances (33). Changes in contractile indices reflect an elevated ventricular inotropic state in the newborn lamb which is postulated to be secondary to elevated circulating CA (34). The importance of circulating CA during the critical period of increased cardiovascular demand in the newborn is suggested by the following: 1) an impaired chronotropic and inotropic responses to hypoxia in newborn sheep following adrenalectomy $(35), 2$ ) hypotension and bradycardia in newborn puppies following adrenalectomy $(36), 3)$ impaired contractile responses to hypoxia in newborn piglets following adrenalectomy (37), and 4) an impaired contractile response following adrenalectomy in newborn dogs compared to adults (38).

Denervation hypersensitivity was suggested by Tabsh et al. (25) to explain the effects of chemical sympathectomy on sensitivity to autonomic agonists. Myocardial BAR were indeed increased in our denervated animals, however, the difference was not significant. It may be possible that the comparable circulatory responses were partially due to increased sensitivity of the denervated animals to the levels of circulating CA. Similarly, the CA surge at birth mediates an increase in glucose via direct glycogenolysis and indirectly by an increase in glucagon and decrease in insulin concentration after delivery. Despite comparable E levels at birth, glucose concentrations in the denervated animals were significantly higher than those of control throughout the experiment. This may also be a reflection of denervation hypersensitivity.

We observed a greater apparent degree of sympathectomy in the heart when compared to the lung or brown adipose tissue. The myocardium at this gestational age is relatively much more densely innervated than the lung parenchyma. The density of innervation and thus uptake of the 6OHDA into sympathetic nerve endings has been proposed as a mechanism for differential sensitivity of various organ systems to this drug (12). Brown adipose tissue is a highly innervated by this gestational age in the lamb, however, the degree of sympathectomy was only partial ( $43 \%$ reduction in tissue NE concentration). This may be due to the different populations of sympathetic neurons in brown adipose tissue where there is a population of short adrenergic neurons which are believed to arise from peripheral ganglia rather than pre- and paravertebral ganglia (39). This population of adrenergic neurons are believed to be more resistant to sympathectomy and indeed this resistance has been suggested by Alexander and Stevens (40) in a study of the effects of 6OHDA on the development of brown adipose tissue in fetal and newborn lambs. This observation or the comparable levels of circulating $\mathrm{E}$ at birth probably account for the similar increases in FFA in denervated and control animals.

In summary, chemical sympathectomy was induced in catheterized fetal sheep in order to determine the source of the increased circulating CA seen at birth and to determine the role of circulating $\mathrm{CA}$ in the maintenance of hemodynamic and metabolic homeostasis in the newborn period. The results suggest that the majority of circulating NE at birth arise from postganglionic sympathetic neurons rather than adrenal medullary se- cretion. The comparable hemodynamic and metabolic changes in the two groups underscore the importance of increased circulating adrenal $\mathrm{E}$ at birth.

\section{REFERENCES}

1. Lagercrantz H, Bistoletti P 1973 Catecholamine release in the newborn infant at birth. Pediatr Res 11:889-893

2. Padbury JF, Polk DH, Newnham JP, Lamm RW 1985 Neonatal adaptation: greater sympathoadrenal response in preterm than full-term fetal sheep at birth. Am J Physiol 248 (Endocrinol Metab 11):E443-E449

3. Padbury JF, Roberman B, Oddie TH, Hobel CJ, Fisher DA 1982 Fetal catecholamine release in response to labor and delivery. Obstet Gynecol 60:607-611

4. Newnham JP, Marshall CL, Padbury JF, Lam RW, Hobel CJ, Fisher DA 1984 Fetal catecholamine release with preterm delivery. Am J Obstet Gynecol 149:888-893

5. Eliot RJ, Klein AH, Glatz TH, Nathanielsz PW, Fisher DA 1981 Plasma norepinephrine, epinephrine, and dopamine concentrations in maternal and fetal sheep during spontaneous parturition and in premature sheep during cortisol-induced parturition. Endocrinology 108:1678-1682

6. Bravo E, Tarazi RC 1982 Plasma catecholamines in clinical investigation: a useful index or a meaningless number? J Lab Clin Med 100:150-160

7. Cryer PE 1980 Physiology and pathophysiology of the human sympathoadrenal neuroendocrine system. N Engl J Med 303:436-444

8. Cohen WR, Piasecki GJ, Jackson BT 1982 Plasma catecholamines during hypoxemia in fetal lamb. Am J Physiol 243 (Regulatory Integrative Comp Physiol 12):R520-R525

9. Comline RS, Silver M 1981 The release of adrenaline and noradrenaline from the adrenal glands of the foetal sheep. J Physiol 156:424-444

10. Comline RS, Silver M 1966 Development of activity in the adrenal medulla of the foetus and newborn animal. Br Med Bull 2:16-20

11. Seidler FJ, Slotkin TA 1985 Adrenomedullary function in the neonatal rat: responses to acute hypoxia. J Physiol 358:1-16

12. Kostrzewa RM, Jacobowitz DM 1974 Pharmacological actions of 6-hydroxydopamine. Pharmacol Rev 26:199-288

13. Lewis AB, Wolf WJ, Sischo W 1984 Fetal cardiovascular and catecholamine responses to hypoxemia after chemical sympathectomy. Pediatr Res 18:318322

14. Craft JB Jr, Coaldrake LA, Yonekura ML, Dao SD, Co EG, Roizen MF, Maze P, Gilman R, Shokes L, Trevor AJ 1983 Ketamine, catecholamines, and uterine tone in pregnant ewes. Am J Obstet Gynecol 146:429-434

15. Lowry OH, Rosebrough NJ, Farr AL, Randall RJ 1951 Protein measurement with the folin phenol reagent. J Biol Chem 193:265-275

16. Peuler JD, Johnson GA 1977 Simultaneous single isotope radioenzymatic assay of plasma norepinephrine, epinephrine and dopamine. Life Sci 21:625636

17. Padbury JF, Diakomanolis ES, Lam RW, Hobel CJ, Fisher DA Ontogenesis of tissue catecholamines in fetal and neonatal rabbits. J Dev Physiol 3:297303

18. Padbury JF, Klein AH, Polk DH, Lam RW, Hobel C, Fisher DA 1986 Effect of thyroid status on lung and heart beta-adrenergic receptors in fetal and newborn sheep. Dev Pharamcol Ther 9:44-53

19. Goloni FG, Sardina LC 1973 Colorimetric microdetermination of free fatty acids. Clin Chem 19:419-424

20. Jobe A, Jacobs H, Ikegami M, Jones S 1983 Cardiovascular effects of surfactant suspensions given by tracheal instillation to premature lambs. Pediatr Res $17: 444-448$

21. Baylen BG, Ogata H, Oguchi K, Ikegami M, Jacobs H, Jobe A, Emmanouilides GC 1985 The contractility and performance of the preterm left ventricle before and early patent ductus arteriosus occlusion in surfactant treated lambs. Pediatr Res 19:1053-1058

22. Sokal RR, Rohlf FJ 1969 Biometry. WH Freeman and Company, San Francisco, pp 299-342

23. Tabsh K, Nuwayhid B, Murad S, Ushioda E, Erkkola R, Brinkman CR III Assali NS 1982 Circulatory effects of chemical sympathectomy in fetal, neonatal, and adult sheep. Am J Physiol 243 (Heart Circ Physiol 12):H113H122

24. Iwamoto HS, Rudolph AM, Mirkin BL, Keil LC 1983 Circulatory and humora responses of sympathectomized fetal sheep to hypoxemia. Am J Physiol 245 (Heart Circ Physiol 14):H767-H772

25. Irestedt L, Lagercrantz H, Hjemdahl P, Hagnevik K, Belfrage P 1982 Fetal and maternal plasma catecholamine levels at elective cesarean section under general or epidural anesthesia versus vaginal delivery. Am J Obstet Gynecol 142:1004-1010

26. Cheah TB, Gefren LB, Jarrott B, Ostberg A 1971 Action of 6-hydroxydopamine on lamb sympathetic ganglia, vas deferens and adrenal medulla: a combined histochemical, ultrastructural and biochemical comparison with the effects of reserpine. Br J Pharmacol 42:543-557

27. Heymann MA, Creasy RK, Rudolph AM 1973 Quantitation of blood flow patterns in the foetal lamb in utero. In: Proceedings of the Sir Joseph Barcroft Centenary Symposium: Foetal and Neonatal Physiology. Cambridge University Press, Cambridge, pp 129-135

28. Breall JA, Rudolph AM, Heymann MA 1984 Role of thyroid hormone in postnatal circulatory and metabolic adjustments. J Clin Invest 73:14181424 
29. Pappano AJ 1977 Ontogenic development of autonomic neuroeffector transmission and transmitter reactivity in embryonic and fetal hearts. Pharmacol Rev 29:3-33

30. Lebowitz EA, Novick JS, Rudolph AM 1972 Development of myocardial sympathetic innervation in the fetal lamb. Pediatr Res 6:887-893

31. Whitsett JA, Noguchi A, Moore JJ 1982 Development aspects of $\alpha$ - and $\beta$ adrenergic receptors. Semin Perinatol 6:125-14

32. Assali NS, Brinkman CR III, Woods JR Jr, Dandavino A, Nuwayhid 1977 Development of neurohormonal control of fetal, neonatal, and adult cardiovascular functions. Am J Obstet Gynecol 129:748-759

33. Rudolph AM 1970 The changes in the circulation after birth. Their importance in congenital heart disease. Circulation XLI:343-359

34. Riemenschneider TA, Brenner RA, Mason DT 1981 Maturational changes in myocardial contractile state of newborn lambs. Pediatr Res 15:349-356

35. Downing SE. Lee JC 1983 Analysis of cardiac adrenergic mechanisms in hypoxic lambs. Am J Physiol 244 (Heart Circ Physiol 13):H222-H227
36. Geis WP, Tatooles CJ, Priola DV, Friedman WF 1975 Factors influencing neurohumoral control of the heart in the newborn dog. Am J Physiol 228:1685-1689

37. Lee JC, Werner JC, Downing SE 1980 Adrenal contribution to cardiac responses elicted by acute hypoxia in piglets. Am J Physiol 239 (Heart Circ Physiol 8):H751-H755

38. Erath HG Jr, Boerth RC, Graham TP Jr 1982 Functional significance of reduced cardiac sympathetic innervation in the newborn dog. Am J Physiol 243 (Heart Circ Physiol 12):H20-H26

39. Levi-Montalcini $T 1972$ The morphological effects of immunosympathectomy. Elsevier, New York, NY, pp 55-78

40. Alexander G, Stevens D 1980 Sympathetic innervation and the development of structure and function of brown adipose tissue: studies on lambs chemically sympathectomized in utero with 6-hydroxydopamine. J Dev Physiol 2:119-137 